\section{EDITORIAL INFORMATION}

One important role played by the nominata is to reflect the performance of the journal over the year. As in previous years, 2015 was a year of much hard work and I wish to thank the authors, reviewers, readers, associate editors, ad hoc editors, editorial board members, and editorial assistants, who carried out their work with professionalism, confidentiality, respect, and a great deal of affection in order to generate knowledge within the scope of the Accounting \& Finance Review.

Having ad hoc editors was a recent experience involving the participation of researchers acting as editors specifically for some articles submitted by professors close to the scientific committee or in some cases of high specificity. Here, I would like to thank the following researchers: Antônio Lopo Martinez, Bruno Funchal, Gilberto José Miranda, and José Alonso Borba.

We are grateful for the financial support received from FIPECAFI, USP, SIBI, and CNPq, which made it possible for activities to be carried out in a way that met the challenges set. Likewise, we wish to thank our service providers, who with professionalism and care contributed to the accomplishment of our work. In particular we would like to mention American Journal Experts, Eva Stal, Evandro Lisboa Freire, Fabiana Cesquim, HG Design Digital, Kris Gillespie, Patrícia Martins Carvalho, and Revisoras.com.br.

I am particularly grateful to SciELO for its support in perfecting the ScholarOne management control system, which enabled a major change in the management standards of the journal. The support provided in implementing the new system was vital.

In 2015 we were accepted by Scopus and this new indexation appears very promising in terms of international visibility.

We received 149 articles submitted in 2015, with 98 reviewers analyzing 105 papers, which led to a $56 \%$ desk rejection rate and a total rejection rate of $82 \%$. We published 25 original articles in editions 67, 68, and 69.

The wide range of topics covered has been the journal's hallmark, and the distribution of articles among the lines of research that make up the scope of the Accounting \& Finance Review was:

\begin{tabular}{lcccc}
\hline Line of Research & Submission & $\%$ & Publication & \% \\
\hline Controllership and Management Accounting & 25 & 18 & 2 & 13 \\
Accounting for External Users & 55 & 37 & 6 & 52 \\
Financial, Credit, and Capital Markets & 51 & 34 & 2 & 24 \\
Accounting Education and Research & 15 & 10 & 2 & 8 \\
Actuarial Science & 2 & 100 & 25 & 100 \\
Total & 149 & & \\
\hline
\end{tabular}

\begin{tabular}{|c|c|c|c|c|}
\hline \multicolumn{5}{|c|}{ Published Articles } \\
\hline \multicolumn{5}{|c|}{ Articles' Institutional Authorship } \\
\hline Issues & & FEA-USP (São Paulo) & Other Institutions & Total \\
\hline \multirow{2}{*}{$\begin{array}{l}\text { Issue } 67 \\
\text { Jan./Apr. }\end{array}$} & Frequency & 6 & 20 & 26 \\
\hline & Percentage & $23.1 \%$ & $76.9 \%$ & $100 \%$ \\
\hline \multirow{2}{*}{$\begin{array}{l}\text { Issue } 68 \\
\text { May/Aug. }\end{array}$} & Frequency & 0 & 23 & 23 \\
\hline & Percentage & $0 \%$ & $100 \%$ & $100 \%$ \\
\hline \multirow{2}{*}{$\begin{array}{l}\text { Issue } 69 \\
\text { Sep./Dec. }\end{array}$} & Frequency & 5 & 18 & 23 \\
\hline & Percentage & $21.7 \%$ & $78.3 \%$ & $100 \%$ \\
\hline Total & & 11 & 61 & 72 \\
\hline Percentage & & $15.3 \%$ & $84.7 \%$ & $100 \%$ \\
\hline Average & & 3.7 & 20.3 & 24 \\
\hline \multicolumn{5}{|c|}{ Published Articles } \\
\hline Issues & & Brazilian & International & Total \\
\hline \multirow{2}{*}{$\begin{array}{l}\text { Issue } 67 \\
\text { Jan./Apr. }\end{array}$} & Frequency & 8 & 0 & 8 \\
\hline & Percentage & $100 \%$ & $0 \%$ & $100 \%$ \\
\hline \multirow{2}{*}{$\begin{array}{l}\text { Issue } 68 \\
\text { May/Aug. }\end{array}$} & Frequency & 6 & 2 & 8 \\
\hline & Percentage & $75 \%$ & $25 \%$ & $100 \%$ \\
\hline \multirow{2}{*}{$\begin{array}{l}\text { Issue } 69 \\
\text { Sep./Dec. }\end{array}$} & Frequency & 9 & 0 & 9 \\
\hline & Percentage & $100 \%$ & $0 \%$ & $100 \%$ \\
\hline Total & & 24 & 2 & 25 \\
\hline Percentage & & $96 \%$ & $4 \%$ & $100 \%$ \\
\hline
\end{tabular}




\begin{tabular}{lcc}
\hline \multicolumn{3}{c}{ Editorial Management } \\
\hline & Authors' & \\
\hline Authors' affiliation & Frequency & Percentage \\
\hline FEA-USP (São Paulo) & 11 & $15.3 \%$ \\
São Paulo (but FEA-USP) & 14 & $19.4 \%$ \\
Other Brazilian States & 41 & $57.0 \%$ \\
International & 6 & $8.3 \%$ \\
Total & $\mathbf{7 2}$ & $\mathbf{1 0 0 . 0} \%$ \\
\hline
\end{tabular}

\begin{tabular}{lcc}
\hline \multicolumn{3}{c}{ Editorial Management } \\
\hline \multicolumn{3}{c}{${\left.\text { Reviewers' }{ }^{*}{ }^{*}\right) \text { Geographic Range de } \mathbf{2 0 1 5}}^{-}$} \\
\hline Reviewers' affiliation & Frequency & Percentage \\
\hline São Paulo & 38 & $38.78 \%$ \\
Other Brazilian States & 48 & $48.98 \%$ \\
International & 12 & $12.24 \%$ \\
Total & $\mathbf{9 8}$ & $\mathbf{1 0 0 . 0} \%$ \\
\hline
\end{tabular}

(*) It representes the amount of reviewers, not the amount of reviews.

\begin{tabular}{|c|c|c|}
\hline \multicolumn{3}{|c|}{ Publication Demand } \\
\hline \multirow{2}{*}{ Articles } & \multicolumn{2}{|c|}{ Jan./Dec. 2015} \\
\hline & Frequency & Percentage \\
\hline Initial outcome of articles in 2015 & 40 & $21.16 \%$ \\
\hline Received & 149 & $78.84 \%$ \\
\hline Total available to the year & 189 & $100.00 \%$ \\
\hline Approved & 25 & $13.23 \%$ \\
\hline Reproved during review & 38 & $20.10 \%$ \\
\hline Rejected before review (desk) & 84 & $44.44 \%(*)$ \\
\hline Total & 122 & $64.55 \%$ \\
\hline In review & 25 & $13.23 \%$ \\
\hline Authors' review & 17 & $9.00 \%$ \\
\hline Total (Final outcome of articles in 2015) & 42 & $22.22 \%$ \\
\hline
\end{tabular}

(*) For the articles submitted only in 2015 , the rejection desk percentage is $56 \%$. 


\section{Adriano Leal Bruni}

UFB - Universidade Federal da Bahia

\section{Alan de Genaro Dario}

FEA - Universidade de São Paulo - Campus Capital

\section{Alexandre de Pádua Carrieri}

UFMG - Universidade Federal de Minas Gerais

\section{Alfredo Sarlo Neto \\ UFES - Universidade Federal do Espírito Santo}

\section{Amaury José Rezende}

FEA - Universidade de São Paulo - Campus Ribeirão Preto

\section{Ana Maria Ribeiro Malho Rodrigues Lourenço}

UC - Universidade de Coimbra - Portugal

\section{André Carlos Aquino} Preto

FEA - Universidade de São Paulo - Campus Ribeirão

\section{Andrea Maria Accioly Fonseca Minardi \\ INSPER - Instituto de Ensino e Pesquisa}

\section{Andson Braga de Aguiar}

FEA - Universidade de São Paulo - Campus Capital

\section{Antonio Carlos Dias Coelho}

UFC - Universidade Federal do Ceará

\section{Aureliano Angel Bressan}

UFMG - Universidade Federal de Minas Gerais

\section{Bruno Dore Rodrigues}

UFJF - Universidade Federal de Juiz de Fora

\section{Bruno Meirelles Salotti}

FEA - Universidade de São Paulo - Campus Capital

\section{Carlos André de Melo Alves}

UnB - Universidade de Brasília

\section{Carlos Bastian-Pinto}

IBMEC - Instituto Brasileiro de Mercado de Capitais Campus Rio de Janeiro

\section{Carlos Eduardo Facin Lavarda}

FURB - Universidade Regional de Blumenau

\section{César Augusto Tibúrcio \\ UnB - Universidade de Brasília}

\section{César Medeiros Cupertino}

SENAC - Serviço Nacional de Aprendizagem - Campus Santa Catarina

\section{Claudia Yoshinaga}

FECAP - Fundação Escola de Comércio Álvares Penteado

\section{Claudio de Araújo Wanderley}

UnB - Universidade de Brasília

\section{Cristiane Benetti}

ICN Business School - França

\section{David Carter}

UC - University of Canberra - Austrália

\section{Diógenes de Souza Bido}

UPM - Universidade Presbiteriana Mackenzie

\section{Edgard Bruno Cornacchione Júnior}

FEA - Universidade de São Paulo - Campus Capital

\section{Edilson Paulo}

UFP - Universidade Federal do Paraná

\section{Eduardo Kazuo Kayo}

FEA - Universidade de São Paulo - Campus Capital 


\section{Elionor Farah Jreige Weffort}

FECAP - Fundação Escola de Comércio Álvares Penteado

\section{Emanuel Rodrigues Junqueira de Matos \\ UFES - Universidade Federal do Espírito Santo}

\section{Ernani Ott}

UNISINOS - Universidade do Vale do Rio dos Sinos

\section{Fabiano Guasti Lima}

FEA - Universidade de São Paulo - Campus Ribeirão Preto

\section{Fabio Garcia Gallo \\ FGV - Fundação Getúlio Vargas - Campus Capital}

\section{Fabio Moraes da Costa}

FUCAPE Business School - ES

\section{Fernando Caio Galdi}

FUCAPE Business School - ES

\section{Fernando Chiqueto da Silva}

FEA - Universidade de São Paulo - Campus Capital

\section{Fernando Dal-Ri Murcia}

FEA - Universidade de São Paulo - Campus Capital

Francisco Henrique Figueiredo de Castro Júnior

FEA - Universidade de São Paulo - Campus Capital

\section{Gilberto José Miranda}

UFU - Universidade Federal de Uberlândia

\section{Guillermo Oscar Braumbeck}

FIPECAFI - SP

\section{Helena Oliveira Isidro}

ISCTE-IUL - Instituto Universitário de Lisboa - Portugal

\section{Hsia Hua Sheng}

FGV - Fundação Getúlio Vargas - Campus Capital

\section{Hugo Marco Consciência Silvestre}

UNILAB - Universidade da Integração Internacional da Lusofonia Afro-Brasileira

\section{Ilirio José Rech}

UFU - Universidade Federal de Uberlândia

\section{Ilse Maria Beuren}

UFPR - Universidade Federal do Paraná

\section{Isabel Maria Estima Costa Lourenço}

IUL - Instituto Universitário de Lisboa - Portugal

\section{Ivam Ricardo Gartner}

UnB - Universidade de Brasília

\section{Jairo Laser Procianoy}

UFRGS - Universidade Federal do Rio Grande do Sul

\section{Janílson Suzart}

Secretaria do Tesouro Nacional

Jerônimo Antunes

FEA - Universidade de São Paulo - Campus Capital

João Pedro Figueiredo Ferreira de Carvalho Oliveira

UPorto - Universidade do Porto - Portugal

João Zani

UNISINOS - Universidade do Vale do Rio dos Sinos

Jorge de Souza Bispo

FIPECAFI - SP

\section{Joshua Imoniana}

FEA - Universidade de São Paulo - Campus Capital 


\section{José Alonso Borba}

UFSC - Universidade Federal de Santa Catarina

José Carlos Tiomatsu Oyadomari

UPM - Universidade Presbiteriana Mackenzie

José Elias Feres de Almeida

UFES - Universidade Federal do Espírito Santo

\section{Joséte Florêncio dos Santos}

UFPE - Universidade Federal de Pernambuco

\section{José Marilson Martins Dantas}

UnB - Universidade de Brasília

\section{Kátia Cristiana Matos Ribeiro Lemos} tugal

IPCA - Instituto Politécnico do Cávado e do Ave - Por-

\section{Lucas Ayres Barreira de Campos Barros} teado

FECAP - Fundação Escola de Comércio Álvares Pen-

\section{Luciano Marcio Scherer}

UFPR - Universidade Federal do Paraná

\section{Luis Paulo Guimarães dos Santos}

UFBA - Universidade Federal da Bahia

\section{Luíz João Corrar}

FEA - Universidade de São Paulo - Campus Capital

\section{Luiz Paulo Lopes Fávero}

FEA - Universidade de São Paulo - Campus Capital

\section{Maísa de Souza Ribeiro}

FEA - Universidade de São Paulo - Campus Ribeirão Preto

Manuel Emilio Mota de Almeida Delgado Castelo Branco

UPorto - Universidade do Porto - Portugal

\section{Marcelo Alvaro da Silva Macedo}

UFRJ - Universidade Federal do Rio de Janeiro

\section{Marcelo Barroso}

UPM - Universidade Presbiteriana Mackenzie

\section{Marcelo Cabus Klotzle}

PUC - Pontifícia Universidade Católica do Rio de Janeiro

\section{Márcia Martins Mendes De Luca}

UFC - Universidade Federal do Ceará

Maria José de Camargo Machado

UNIMEP - Universidade Metodista de Piracicaba

Mário António Augusto

UC - Universidade de Coimbra - Portugal

\section{Nálbia de Araújo Santos}

UFV - Universidade Federal de Viçosa

\section{Orleans Silva Martins}

UFPB - Universidade Federal da Paraíba

Otávio Ribeiro de Medeiros

UnB - Universidade de Brasília

\section{Patrícia de Souza Costa}

UFU - Universidade Federal de Uberlândia

\section{Paulo Miguel da Silva Cardoso}

UEvora - Universidade de Évora - Portugal

\section{Rafael Felipe Schiozer}

FGV - Fundação Getúlio Vargas - Campus Capital

\section{Ralph Melles Sticca}

FGV - Fundação Getúlio Vargas - Campus Capital

\section{Reinaldo Guerreiro}

FEA - Universidade de São Paulo - Campus Capital 


\section{Renê Coppe Pimentel}

Faculdade Fipecafi

FUCAPE Business School - ES

\section{Richard Saito}

FGV - Fundação Getúlio Vargas - Campus Capital

\section{Roberto Carlos Klann}

FURB - Universidade Regional de Blumenau

\section{Robson Zuccolotto}

UFV - Universidade Federal de Viçosa

\section{Romildo de Oliveira Moraes}

UEM - Universidade Estadual de Maringá

\section{Romualdo Douglas Colauto}

UFPR - Universidade Federal do Paraná

\section{Rosimeire Pimentel Gonzaga}

UFMG - Universidade Federal de Minas Gerais

\section{Rui Vieira}

UvA - University of Amsterdam - Holanda

\section{Ruy Monteiro Ribeiro}

PUC - Pontifícia Universidade Católica do Rio de Janeiro

\section{Sandro Eduardo Monsueto}

UFG - Universidade Federal de Goiás

\section{Sérgio de Iudícibus}

FEA - Universidade de São Paulo - Campus Capital

\section{Sheizi Calheira de Freitas}

UFBA - Universidade Federal da Bahia

\section{Tania Casado}

FEA - Universidade de São Paulo - Campus Capital

\section{Tatiana Albanez}

FEA - Universidade de São Paulo - Campus Capital

\section{Wesley Mendes-da-Silva}

FGV - Fundação Getúlio Vargas - Campus Capital

\section{Wilson Luiz Rotatori Corrêa}

UFJF - Universidade Federal de Juiz de Fora

\section{Wilson Toshiro Nakamura}

UPM - Universidade Presbiteriana Mackenzie

Xiomara Esther Vásquez Carrazana

UFU - Universidade Federal de Uberlândia

\section{Yara Consuelo Cintra}

UFRJ - Universidade Federal do Rio de Janeiro 


\section{Index by Title}

Accounting Choices: the Brazilian Case of Real Estate Investment

PINTO, Murillo José Torello; MARTINS, Vinícius Aversari; SILVA, Denise Mendes da

v.26, n.69, p.274-289, Sep./Dec.2015

Adoption of the International Accounting Standard by Small and Medium-Sized Entities and its Effects on Credit Granting

RIVA, Enrico Dalla; SALOTTI, Bruno Meirelles

v.26, n.69, p.304-316, Sep./Dec.2015

An Analysis of Differences in Terms of Professional Interests Based on the Project to Replace IAS 39

CARVALHO, Cláudia Daniela Ferreira da Mota; ALBUQUERQUE, Fábio Henrique Ferreira de; QUIRÓS, Joaquín Texeira; JUSTINO, Maria do Rosário Fernandes

v.26, n.68, p.181-194, May/Aug.2015

Analysis of the Relevance of Information Content of the Value Added Statement in the Brazilian Capital Markets

MACHADO, Márcio André Veras; MACEDO, Marcelo Alvaro da Silva; MACHADO, Márcia Reis

v.26, n.67, p.57-69, Jan./Apr.2015

Assessment of the Methodological Rigor of Case Studies in the Field of Management Accounting Published in Journals in Brazil

MARQUES, Kelly Cristina Mucio; CAMACHO, Reinaldo Rodrigues; ALCANTARA, Caio Cesar Violin

v.26, n.67, p.27-42, Jan./Apr.2015

Avoiding Reporting Losses - An Empirical Study of Earnings Management via Operating Decisions

REIS, Elizio Marcos dos; LAMOUNIER, Wagner Moura; BRESSAN, Valéria Gama Fully

v.26, n.69, p.247-260, Sep./Dec.2015

Basel III: Impact on Banks in Brazil

PINHEIRO, Fernando Antonio Perrone; SAVÓIA, José Roberto Ferreira; SECURATO, José Roberto

v.26, n.69, p.345-361, Sep./Dec.2015

Capital structure: the role of the funding sources on which Brazilian listed companies are based

TARANTIN JUNIOR, Wilson; VALLE, Maurício Ri- beiro do

v.26, n.69, p.331-344, Sep./Dec.2015

Comparability of Accounting Choices in Future Valuation of Investment Properties: An Analysis of Brazilian and Portuguese Listed Companies

SOUZA, Flaida Êmine Alves de; BOTINHA, Reiner Alves; SILVA, Pablo Rogers; LEMES, Sirlei

v.26, n.68, p.154-166, May/Aug.2015

Comparing the Use of Forward-Looking and Contemporary Performance Measurement to Formulate Incentive Contracts in the Presence of the Horizon Problem: An Experimental Analysis

SANTOS, Luis Paulo Guimarães dos

v.26, n.68, p.195-207, May/Aug.2015

Determinant Factors of Dividend Payments in Brazil

FORTI, Cristiano Augusto Borges; PEIXOTO, Fernanda Maciel; ALVES, Denis Lima e

v.26, n.68, p.167-180, May/Aug.2015

Determinants of Audit Fees: a Study in the Companies Listed on the BM\&FBOVESPA, Brazil

CASTRO, Walther Bottaro de Lima; PELEIAS, Ivam Ricardo; SILVA, Glauco Peres da

v.26, n.69, p.261-273, Sep./Dec.2015

Determinants of Financial Literacy: Analysis of the Influence of Socioeconomic and Demographic Variables

POTRICH, Ani Caroline Grigion; VIEIRA, Kelmara Mendes; KIRCH, Guilherme

v.26, n.69, p.362-377, Sep./Dec.2015

Determinants of Supply and Demand for Trade Credit by Micro, Small and Medium-Sized Enterprises

CARVALHO, Claudinê Jordão de; SCHIOZER, Rafael Felipe

v.26, n.68, p.208-222, May/Aug.2015

Determining Factors for Delisting of Companies Listed on BM\&FBOVESPA

BORTOLON, Patricia Maria; SILVA JUNIOR, Annor da

v.26, n.68, p.140-153, May/Aug.2015 
Do Shared Interests Affect the Accuracy of Budgets?

BEUREN, Ilse Maria; BECK, Franciele; POPIK, Fabiane

v.26, n.67, p.11-26, Jan./Apr.2015

Exit and Failure of Credit Unions in Brazil: A Risk Analysis

CARVALHO, Flávio Leonel de; DIAZ, Maria Dolores Montoya; BIALOSKORSKI NETO, Sigismundo; KALATZIS, Aquiles Elie Guimarães

$$
\text { v.26, n.67, p.70-84, Jan./Apr.2015 }
$$

Impact of Retirements and Pensions on the Social Welfare of the Households from Minas Gerais State

REIS, Paulo Ricardo da Costa; SILVEIRA, Suely de Fátima Ramos; BRAGA, Marcelo José; COSTA, Thiago de Melo Teixeira da

v.26, n.67, p.106-118, Jan./Apr.2015

Information Asymmetry and Pricing of Shares: Analysis of the Use of Social Networks in the Brazilian and North American Capital Markets

ARRUDA, Marcelo Paulo; GIRÃO, Luiz Felipe de Araújo Pontes; LUCENA, Wenner Glaucio Lopes

v.26, n.69, p.317-330, Sep./Dec.2015

Is There a Difference in Credit Constraints Between Private and Listed Companies in Brazil? Empirical Evidence by The Cash Flow Sensitivity Approach

GHANI, Alan Nader Ackel; MARTELANC, Roy; KAYO, Eduardo Kazuo v.26, n.67, p.85-92, Jan./Apr.2015

Main Consequences of IFRS Adoption: Analysis of Existing Literature and Suggestions for Further Research

LOURENÇO, Isabel Maria Estima Costa; BRANCO, Manuel Emílio Mota de Almeida Delgado Castelo

v.26, n.68, p.126-139, May/Aug.2015

Perceived Problems of Being an Accounting Teacher

ARAÚJO, Tamires Sousa; LIMA, Francielly Dornellas Correia; OLIVEIRA, Ana Clara Lacerda de; MIRANDA, Gilberto José

v.26, n.67, p.93-105, Jan./Apr.2015

Quality Determinants of Independent Audits of Banks

DANTAS, José Alves; MEDEIROS, Otavio Ribeiro de v.26, n.67, p.43-56, Jan./Apr.2015

The Term Structure of Interest Rates and its Impact on the Liability Adequacy Test for Insurance Companies in Brazil

DUARTE, Antonio Aurelio; SILVA, Aldy Fernandes da; OLIVEIRA, Luciano Vereda; WEFFORT, Elionor Farah Jreige; CHAN, Betty Lilian

v.26, n.68, p.223-236, May/Aug.2015

Unexpected Earnings, Stock Returns, and Risk in the Brazilian Capital Market

PIMENTEL, Renê Coppe

v.26, n.69, p.290-303, Sep./Dec.2015 


\section{Index by Author}

ALBUQUERQUE, Fábio Henrique Ferreira de

An Analysis of Differences in Terms of Professional Interests Based on the Project to Replace IAS 39

v.26, n.68, p.181-194, May/Aug.2015

\section{ALCANTARA, Caio Cesar Violin}

Assessment of the Methodological Rigor of Case Studies in the Field of Management Accounting Published in Journals in Brazil

v.26, n.67, p.27-42, Jan./Apr.2015

\section{ALVES, Denis Lima e}

Determinant Factors of Dividend Payments in Brazil v.26, n.68, p.167-180, May/Aug.2015

\section{ARAÚJO, Tamires Sousa}

Perceived Problems of Being an Accounting Teacher v.26, n.67, p.93-105, Jan./Apr.2015

\section{ARRUDA, Marcelo Paulo de}

Information Asymmetry and Pricing of Shares: Analysis of the Use of Social Networks in the Brazilian and North American Capital Markets

v.26, n.69, p.317-330, Sep./Dec.2015

\section{BECK, Franciele}

Do Shared Interests Affect the Accuracy of Budgets? v.26, n.67, p.11-26, Jan./Apr.2015

\section{BEUREN, Ilse Maria}

Do Shared Interests Affect the Accuracy of Budgets? v.26, n.67, p.11-26, Jan./Apr.2015

\section{BIALOSKORSKI NETO, Sigismundo}

Exit and Failure of Credit Unions in Brazil: A Risk Analysis

v.26, n.67, p.70-84, Jan./Apr.2015

\section{BORTOLON, Patricia Maria}

Determining Factors for Delisting of Companies Listed on BM\&FBOVESPA

v.26, n.68, p.140-153, May/Aug.2015

\section{BOTINHA, Reiner Alves}

Comparability of Accounting Choices in Future Valuation of Investment Properties: An Analysis of Brazilian and Portuguese Listed Companies

v.26, n.68, p.154-166, May/Aug.2015

\section{BRAGA, Marcelo José}

Impact of Retirements and Pensions on the Social Welfare of the Households from Minas Gerais State

v.26, n.67, p.106-118, Jan./Apr.2015

BRANCO, Manuel Emílio Mota de Almeida Delgado Castelo

Main Consequences of IFRS Adoption: Analysis of Existing Literature and Suggestions for Further Research

v.26, n. 68, p.126-139, May/Aug.2015

BRESSAN, Valéria Gama Fully

Avoiding Reporting Losses - An Empirical Study of Earnings Management via Operating Decisions

v.26, n.69, p.247-260, Sep./Dec.2015

CAMACHO, Reinaldo Rodrigues

Assessment of the Methodological Rigor of Case Studies in the Field of Management Accounting Published in Journals in Brazil

v.26, n.67, p.27-42, Jan./Apr.2015

CARVALHO, Cláudia Daniela Ferreira da Mota

An Analysis of Differences in Terms of Professional Interests Based on the Project to Replace IAS 39

v.26, n.68, p.181-194, May/Aug.2015

CARVALHO, Claudinê Jordão de

Determinants of Supply and Demand for Trade Credit by Micro, Small and Medium-Sized Enterprises

v.26, n.68, p.208-222, May/Aug.2015

CARVALHO, Flávio Leonel de

Exit and Failure of Credit Unions in Brazil: A Risk Analysis

v.26, n.67, p.70-84, Jan./Apr.2015 


\section{CASTRO, Walther Bottaro de Lima}

Determinants of Audit Fees: a Study in the Companies Listed on the BM\&FBOVESPA, Brazil

v.26, n.69, p.261-273, Sep./Dec.2015

\section{CHAN, Betty Lilian}

The Term Structure of Interest Rates and its Impact on the Liability Adequacy Test for Insurance Companies in Brazil

v.26, n.68, p.223-236, May/Aug.2015

COSTA, Thiago de Melo Teixeira da

Impact of Retirements and Pensions on the Social Welfare of the Households from Minas Gerais State

v.26, n.67, p.106-118, Jan./Apr.2015

\section{DANTAS, José Alves} Banks

Quality Determinants of Independent Audits of v.26, n.67, p.43-56, Jan./Apr.2015

\section{DIAZ, Maria Dolores Montoya}

Exit and Failure of Credit Unions in Brazil: A Risk Analysis

v.26, n.67, p.70-84, Jan./Apr.2015

\section{DUARTE, Antonio Aurelio}

The Term Structure of Interest Rates and its Impact on the Liability Adequacy Test for Insurance Companies in Brazil

v.26, n.68, p.223-236, May/Aug.2015

\section{FORTI, Cristiano Augusto Borges}

Determinant Factors of Dividend Payments in Brazil

v.26, n.68, p.167-180, May/Aug.2015

\section{GHANI, Alan Nader Ackel}

Is There a Difference in Credit Constraints Between Private and Listed Companies in Brazil? Empirical Evidence by The Cash Flow Sensitivity Approach

v.26, n.67, p.85-92, Jan./Apr.2015

\section{GIRÃO, Luiz Felipe de Araújo Pontes}

Information Asymmetry and Pricing of Shares: Analysis of the Use of Social Networks in the Brazilian and North American Capital Markets

v.26, n.69, p.317-330, Sep./Dec.2015

JUSTINO, Maria do Rosário Fernandes

An Analysis of Differences in Terms of Professional Interests Based on the Project to Replace IAS 39

v.26, n.68, p.181-194, May/Aug.2015

KALATZIS, Aquiles Elie Guimarães

Exit and Failure of Credit Unions in Brazil: A Risk Analysis

v.26, n.67, p.70-84, Jan./Apr.2015

\section{KAYO, Eduardo Kazuo}

Is There a Difference in Credit Constraints Between Private and Listed Companies in Brazil? Empirical Evidence by The Cash Flow Sensitivity Approach

v.26, n.67, p.85-92, Jan./Apr.2015

\section{KIRCH, Guilherme}

Determinants of Financial Literacy: Analysis of the Influence of Socioeconomic and Demographic Variables

v.26, n.69, p.362-377, Sep./Dec.2015

\section{LAMOUNIER, Wagner Moura}

Avoiding Reporting Losses - An Empirical Study of Earnings Management via Operating Decisions

v.26, n.69, p.247-260, Sep./Dec.2015

\section{LEMES, Sirlei}

Comparability of Accounting Choices in Future Valuation of Investment Properties: An Analysis of Brazilian and Portuguese Listed Companies

v.26, n.68, p.154-166, May/Aug.2015

\section{LIMA, Francielly Dornellas Correia}

Perceived Problems of Being an Accounting Teacher v.26, n.67, p.93-105, Jan./Apr.2015

\section{LOURENÇO, Isabel Maria Estima Costa}

Main Consequences of IFRS Adoption: Analysis of Existing Literature and Suggestions for Further Research

v.26, n. 68, p.126-139, May/Aug.2015 


\section{LUCENA, Wenner Glaucio Lopes}

Information Asymmetry and Pricing of Shares: Analysis of the Use of Social Networks in the Brazilian and North American Capital Markets

v.26, n.69, p.317-330, Sep./Dec.2015

\section{MACEDO, Marcelo Alvaro da Silva}

Analysis of the Relevance of Information Content of the Value Added Statement in the Brazilian Capital Markets

v.26, n.67, p.57-69, Jan./Apr.2015

\section{MACHADO, Márcia Reis}

Analysis of the Relevance of Information Content of the Value Added Statement in the Brazilian Capital Markets

v.26, n.67, p.57-69, Jan./Apr.2015

\section{MACHADO, Márcio André Veras}

Analysis of the Relevance of Information Content of the Value Added Statement in the Brazilian Capital Markets

v.26, n.67, p.57-69, Jan./Apr.2015

\section{MARQUES, Kelly Cristina Mucio}

Assessment of the Methodological Rigor of Case Studies in the Field of Management Accounting Published in Journals in Brazil

v.26, n.67, p.27-42, Jan./Apr.2015

\section{MARTELANC, Roy}

Is There a Difference in Credit Constraints Between Private and Listed Companies in Brazil? Empirical Evidence by The Cash Flow Sensitivity Approach

v.26, n.67, p.85-92, Jan./Apr.2015

MARTINS, Vinícius Aversari

Accounting Choices: the Brazilian Case of Real Estate Investment

v.26, n.69, p.274-289, Sep./Dec.2015

\section{MEDEIROS, Otavio Ribeiro de}

Quality Determinants of Independent Audits of Banks v.26, n.67, p.43-56, Jan./Apr.2015

\section{MIRANDA, Gilberto José}

Perceived Problems of Being an Accounting Teacher v.26, n.67, p.93-105, Jan./Apr.2015
OLIVEIRA, Ana Clara Lacerda de

Perceived Problems of Being an Accounting Teacher v.26, n.67, p.93-105, Jan./Apr.2015

\section{OLIVEIRA, Luciano Vereda}

The Term Structure of Interest Rates and its Impact on the Liability Adequacy Test for Insurance Companies in Brazil

v.26, n.68, p.223-236, May/Aug.2015

\section{PEIXOTO, Fernanda Maciel}

Determinant Factors of Dividend Payments in Brazil v.26, n.68, p.167-180, May/Aug.2015

\section{PELEIAS, Ivam Ricardo}

Determinants of Audit Fees: a Study in the Companies Listed on the BM\&FBOVESPA, Brazil

v.26, n.69, p.261-273, Sep./Dec.2015

\section{PIMENTEL, Renê Coppe}

Unexpected Earnings, Stock Returns, and Risk in the Brazilian Capital Market

v.26, n.69, p.290-303, Sep./Dec.2015

PINHEIRO, Fernando Antonio Perrone

Basel III: Impact on Banks in Brazil

v.26, n.69, p.345-361, Sep./Dec.2015

PINTO, Murillo José Torello

Accounting Choices: the Brazilian Case of Real Estate Investment

v.26, n.69, p.274-289, Sep./Dec.2015

POPIK, Fabiane

Do Shared Interests Affect the Accuracy of Budgets? v.26, n.67, p.11-26, Jan./Apr.2015

\section{POTRICH, Ani Caroline Grigion}

Determinants of Financial Literacy: Analysis of the Influence of Socioeconomic and Demographic Variables

v.26, n.69, p.362-377, Sep./Dec.2015

QUIRÓS, Joaquín, Texeira

An Analysis of Differences in Terms of Professional In- 
terests Based on the Project to Replace IAS 39

v.26, n.68, p.181-194, May/Aug.2015

REIS, Elizio Marcos dos

Avoiding Reporting Losses - An Empirical Study of Earnings Management via Operating Decisions

v.26, n.69, p.247-260, Sep./Dec.2015

\section{REIS, Paulo Ricardo da Costa}

Impact of Retirements and Pensions on the Social Welfare of the Households from Minas Gerais State v.26, n.67, p.106-118, Jan./Apr.2015

\section{RIVA, Enrico Dalla}

Adoption of the International Accounting Standard by Small and Medium-Sized Entities and its Effects on Credit Granting

v.26, n.69, p.304-316, Sep./Dec.2015

\section{SALOTTI, Bruno Meirelles}

Adoption of the International Accounting Standard by Small and Medium-Sized Entities and its Effects on Credit Granting

v.26, n.69, p.304-316, Sep./Dec.2015

SANTOS, Luis Paulo Guimarães dos

Comparing the Use of Forward-Looking and Contemporary Performance Measurement to Formulate Incentive Contracts in the Presence of the Horizon Problem: An Experimental Analysis

v.26, n.68, p.195-207, May/Aug.2015

\section{SAVÓIA, José Roberto Ferreira}

Basel III: Impact on Banks in Brazil

v.26, n.69, p.345-361, Sep./Dec.2015

\section{SCHIOZER, Rafael Felipe}

Determinants of Supply and Demand for Trade Credit by Micro, Small and Medium-Sized Enterprises

v.26, n.68, p.208-222, May/Aug.2015

SECURATO, José Roberto

Basel III: Impact on Banks in Brazil

v.26, n.69, p.345-361, Sep./Dec.2015
SILVA, Aldy Fernandes da

The Term Structure of Interest Rates and its Impact on the Liability Adequacy Test for Insurance Companies in Brazil

v.26, n.68, p.223-236, May/Aug.2015

SILVA, Denise Mendes da

Accounting Choices: the Brazilian Case of Real Estate Investment

v.26, n.69, p.274-289, Sep./Dec.2015

SILVA, Glauco Peres da

Determinants of Audit Fees: a Study in the Companies Listed on the BM\&FBOVESPA, Brazil

v.26, n.69, p.261-273, Sep./Dec.2015

\section{SILVA, Pablo Rogers}

Comparability of Accounting Choices in Future Valuation of Investment Properties: An Analysis of Brazilian and Portuguese Listed Companies

v.26, n.68, p.154-166, May/Aug.2015

\section{SILVA JUNIOR, Annor da}

Determining Factors for Delisting of Companies Listed on BM\&FBOVESPA

v.26, n.68, p.140-153, May/Aug.2015

SILVEIRA, Suely de Fátima Ramos

Impact of Retirements and Pensions on the Social Welfare of the Households from Minas Gerais State

v.26, n.67, p.106-118, Jan./Apr.2015

SOUZA, Flaida Êmine Alves de

Comparability of Accounting Choices in Future Valuation of Investment Properties: An Analysis of Brazilian and Portuguese Listed Companies

v.26, n.68, p.154-166, May/Aug.2015

\section{TARANTIN JUNIOR, Wilson}

Capital structure: the role of the funding sources on which Brazilian listed companies are based

v.26, n.69, p.331-344, Sep./Dec.2015 


\section{VALLE, Maurício Ribeiro do}

Capital structure: the role of the funding sources on which Brazilian listed companies are based

v.26, n.69, p.331-344, Sep./Dec.2015

\section{VIEIRA, Kelmara Mendes}

Determinants of Financial Literacy: Analysis of the Influence of Socioeconomic and Demographic Variables v.26, n.69, p.362-377, Sep./Dec.2015

\section{WEFFORT, Elionor Farah Jreige}

The Term Structure of Interest Rates and its Impact on the Liability Adequacy Test for Insurance Companies in Brazil

v.26, n.68, p.223-236, May/Aug.2015

Once more, thank you!

Fábio Frezatti, Editor-in-Chief of A\&FR 